\title{
Sensory evaluation of cooked new sweet potato selections'
}

\author{
Franklin W. Martin and Isabel Beauchamp de Caloni ${ }^{2}$
}

\begin{abstract}
Twelve new sweet potato selections varying in visible characteristics were cooked and evaluated by five groups: a trained taste panel, an untrained taste panel, families in their homes, Haitian agronomists, and elderly people in a retirement home. The characteristics evaluated were appearance, mouthfeel (perceived texture), flavor, sweetness, and overall acceptability. Only one selection was rejected by all groups that tried it, SPV 52, a non-5weet, very dry type. Among the remaining selections, SPV $44,55,56,70$ and 71 were highly rated. Selection SPV 70 is not sweet, but was very highly rated by the Haitian agronomists, the untrained panel, and the families. Two orange-fleshed cultivars were readily accepted (SPV 43 and 46). Overall acceptability was correlated with mouthfeel and flavor, but not with appearance or sweetness.
\end{abstract}

\section{INTRODUCTION}

The sweet potato (Ipomoea batatas L. Lam.) arrived in the Caribbean before the time of Colombus, and from the limited germplasm numerous local or creole cultivars developed. These are sometimes quite productive but highly variable in quality. There is a clear need for better cultivars.

In the improvement and distribution of new cultivars, emphasis should be placed on quality as reflected in human preferences. Sweet potatoes are highly variable with respect to characteristics which affect their quality as foods. Those that are orange fleshed, very sweet, and moist in the mouth have been accepted as ideal in the United States (7) and are used chiefly as dessert vegetables. Tropical cultivars introduced to Florida from Cuba, called boniatos, are usually less sweet, white or yellow, drier in the mouth, and are used as principal starchy dishes (1). A new type of sweet potato, selected and described by Martin (1986), called staple, is low in sugar content and suitable for everyday use. This new type is represented in a series of sweet potato selections that range from non-sweet to low sweet because of low initial sweetness and/or little

'Manuscript submitted to Editorial Board 9 February 1987.

2Tropical Agricultural Research Station Agricultural, Research Service, U. S Department of Agriculture, and Associate Food Technologist, Food Technology Laboratory, Agricultural Experiment Station, Río Piedras, Puerto Rico. The authors wish to acknowledge the highly appreciated assistance of Ms. Ruth Ruberté in the laboratory and Mrs. Eleanor Fontanet de Gotay, with the statisties. 
TABLE 1.-Characteristics of 13 sweet potato selections

\begin{tabular}{clcccc}
\hline Selections & $\begin{array}{c}\text { Color after } \\
\text { cooking }\end{array}$ & $\begin{array}{c}\text { Percent } \\
\text { dry weight }\end{array}$ & $\begin{array}{c}\text { Percent } \\
\text { starches }^{1}\end{array}$ & $\begin{array}{c}\text { Percent } \\
\text { protein }^{1}\end{array}$ & $\begin{array}{c}\text { Percent sugars } \\
\text { after cooking }^{1}\end{array}$ \\
\hline SPV 46 & Orange & 29.1 & 18.5 & 2.2 & 35.6 \\
SPV 66 & Cream & 35.4 & 27.6 & 4.4 & 16.3 \\
SPV 63 & Whitish & 31.2 & 22.2 & 5.6 & 22.0 \\
SPV 60 & Yellowish & 39.6 & 28.6 & 4.1 & 16.9 \\
SPV 70 & White & 36.6 & 17.2 & 4.5 & 6.2 \\
SPV 65 & Whitish & 36.9 & 32.0 & 4.2 & 11.1 \\
SPV 52 & Gray & 31.7 & 22.1 & 3.3 & 6.5 \\
SPV 44 & White & 38.4 & 19.8 & 1.9 & 13.4 \\
SPV 64 & Whitish & 43.0 & 22.0 & 6.1 & 35.2 \\
SPV 43 & Orange & 30.2 & 20.1 & 1.2 & 30.1 \\
SPV 71 & Yellow & 20.8 & 16.2 & 3.5 & 12.4 \\
SPV 55 & Whitish & 38.2 & 24.8 & 4.4 & 33.4 \\
SPV 56 & Whitish & 39.1 & 31.0 & 3.4 & 23.1 \\
\hline
\end{tabular}

'Dry weight basis.

conversion of starch on cooking (5). These newly-developed sweet potatoes were tested for their acceptance in both laboratory and home trials, in Puerto Rico and in Haiti.

\section{MATERIALS AND METHODS}

The selections of sweet potato used in this study and some of their characteristics are listed in table 1 . These sweet potatoes were tested for acceptance in five trials. The selections included in each trial are those that were available at the moment.

In the first trial (Río Piedras), 9 selections of sweet potato were cut into thick $(2.5 \mathrm{~cm}$ ) slices, peeled and boiled until tender (about $20 \mathrm{~min}$ utes). Table 2 shows results when samples were evaluated by a trained taste panel of 10 to 16 members on a 5-point scale for appearance, mouthfeel (texture), flavor, sweetness, and overall acceptability according to Larmond's method (3).

\begin{tabular}{|c|c|}
\hline Characteristic & Interpretation of Scale \\
\hline Appearance & $\begin{array}{l}1=\text { not attractive, } \\
5=\text { very attractive. }\end{array}$ \\
\hline Mouthfeel $^{\mathrm{a}}$ & $\begin{array}{c}1=\text { very dry, } 5=\text { very } \\
\text { moist. }\end{array}$ \\
\hline Flavor & $\begin{array}{l}1=\text { not flavorful, } \\
\quad 5=\text { very flavorful. }\end{array}$ \\
\hline Sweetness & $\begin{array}{l}1=\text { not sweet, } \\
5=\text { very sweet. }\end{array}$ \\
\hline cceptability & $\begin{array}{l}1=\text { not acceptable } \\
5=\text { very acceptabl }\end{array}$ \\
\hline
\end{tabular}

In the first trial this scale was used as $1=$ not acceptable, $5=$ very acceptable. In the other trials the scale above was used. Selections were compared by analysis of variance. 
TABLE 2.-Sensory evaluation of boiled sweet potato selections by trained panel

\begin{tabular}{cccccc}
\hline & \multicolumn{5}{c}{ Mean values } \\
\cline { 2 - 6 } Selection & Appearance & Texture & Flavor & Sweetness & $\begin{array}{c}\text { Overall } \\
\text { acceptability }\end{array}$ \\
\hline SPV 46 & 4.3 & $3.3 \mathrm{a}^{2}$ & $3.2 \mathrm{a}$ & $4.0 \mathrm{a} \mathrm{b}$ & $3.7 \mathrm{a}$ \\
SPV 63 & 4.2 & $3.7 \mathrm{a}$ & $3.5 \mathrm{a}$ & $3.8 \mathrm{a} \mathrm{b}$ & $3.8 \mathrm{a}$ \\
SPV 71 & 4.2 & $3.9 \mathrm{a}$ & $3.5 \mathrm{a}$ & $3.2 \mathrm{~b}$ & $4.2 \mathrm{a}$ \\
SPV 60 & 4.2 & $3.8 \mathrm{a}$ & $3.7 \mathrm{a}$ & $4.0 \mathrm{~b}$ & $4.0 \mathrm{a}$ \\
SPV 52 & 3.7 & $2.5 \mathrm{~b}$ & $1.2 \mathrm{~b}$ & $1.9 \mathrm{c}$ & $2.7 \mathrm{~b}$ \\
SPV 44 & 3.4 & $3.8 \mathrm{a}$ & $4.0 \mathrm{a}$ & $4.3 \mathrm{a}$ & $4.0 \mathrm{a}$ \\
SPV 43 & 3.5 & $3.4 \mathrm{a}$ & $3.6 \mathrm{a}$ & $3.8 \mathrm{a} \mathrm{b}$ & $4.1 \mathrm{a}$ \\
SPV 55 & 4.1 & $3.9 \mathrm{a}$ & $3.8 \mathrm{a}$ & $3.7 \mathrm{a} \mathrm{b}$ & $4.2 \mathrm{a}$ \\
SPV 56 & 3.7 & $3.8 \mathrm{a}$ & $3.3 \mathrm{a}$ & $3.7 \mathrm{a} \mathrm{b}$ & $3.7 \mathrm{a}$ \\
\hline
\end{tabular}

${ }^{1} 5$ point scale.

$\begin{array}{ll}\text { Appearance } & 1=\text { do not like, } 5=\text { like very much. } \\ \text { Texture } & 1=\text { poor, } 5=\text { excellent. } \\ \text { Flavor } & 1=\text { poor, } 5=\text { excellent. } \\ \text { Sweetness } & 1=\text { not sweet, } 5=\text { very sweet. } \\ \text { Overall Acceptability } & 1=\text { do not like, } 5=\text { like very much. }\end{array}$

${ }^{2}$ Means followed by one or more letters in common in same column do not differ significantly at $5 \%$ probability.

In the second trial (Mayagüez), storage roots of 8 selections were cut into $2.5 \mathrm{~cm}$ cubes, boiled 18 to $20 \mathrm{~min}$ until soft, and presented in groups of 5 to 27 untrained panel members. The panel members were instructed to observe, taste, and judge the sweet potatoes on a scale of 1 to 5 as previously described. The results shown in table 3 were subject to analysis of variance and correlation analysis.

In the third trial (Mayagüez), each of 10 selections of sweet potato was given to 5 different families with instructions to cook them in the family's way and serve it with dinner. The family then filled in a questionnaire which included ratings of appearance, texture, and sweetness,

TABLE 3.-Ratings of 8 boiled sweet potato selections for quality characteristics by untrained panel

\begin{tabular}{lccccc}
\hline & \multicolumn{4}{c}{ Characteristics } & Overall \\
\cline { 2 - 5 } Selection & Appearance & Mouthfeel & Flavor & Sweetness & acceptability \\
\hline SPV 63 & $3.8 \mathrm{a}^{1}$ & $3.6 \mathrm{ab}$ & $3.9 \mathrm{a}$ & $3.5 \mathrm{a}$ & $3.5 \mathrm{a}$ \\
SPV 60 & $3.1 \mathrm{~b}$ & $2.6 \mathrm{bc}$ & $2.7 \mathrm{bc}$ & $2.0 \mathrm{c}$ & $3.1 \mathrm{bc}$ \\
SPV 70 & $3.8 \mathrm{a}$ & $3.5 \mathrm{ab}$ & $3.8 \mathrm{ab}$ & $1.2 \mathrm{~d}$ & $3.7 \mathrm{a}$ \\
SPV 65 & $2.7 \mathrm{~b}$ & $2.4 \mathrm{bc}$ & $2.8 \mathrm{bc}$ & $2.2 \mathrm{bc}$ & $2.7 \mathrm{c}$ \\
SPV 52 & $1.9 \mathrm{c}$ & $1.6 \mathrm{~d}$ & $2.3 \mathrm{c}$ & $1.3 \mathrm{~d}$ & $1.9 \mathrm{~d}$ \\
SPV 64 & $3.6 \mathrm{a}$ & $4.0 \mathrm{a}$ & $3.3 \mathrm{~b}$ & $2.0 \mathrm{c}$ & $3.4 \mathrm{ab}$ \\
SPV 55 & $3.2 \mathrm{ab}$ & $3.6 \mathrm{ab}$ & $3.7 \mathrm{a}$ & $3.0 \mathrm{ab}$ & $3.3 \mathrm{ab}$ \\
SPV 56 & $3.8 \mathrm{ab}$ & $3.1 \mathrm{bc}$ & $3.4 \mathrm{ab}$ & $2.6 \mathrm{abc}$ & $3.5 \mathrm{a}$ \\
\hline
\end{tabular}

${ }^{1}$ Means in columns followed by one or more letters in common do not differ significantly at the $5 \%$ probability level. 
TABLE 4.-Summary of ratings of sweet potatoes in the home by families

\begin{tabular}{lccccl}
\hline & \multicolumn{4}{c}{ Ratings by the Families } & \\
\cline { 2 - 5 } Selection & Appearance & Texture & Sweetness & Acceptability & \multicolumn{1}{c}{ Comments } \\
\hline SPV 63 & $4.4^{1}$ & 3.2 & 2.0 & 4.3 & Good Flavor \\
SPV 60 & 3.8 & 2.0 & 2.3 & 4.0 & Somewhat dry \\
SPV 70 & 4.3 & 3.3 & 1.2 & 4.5 & Potato like \\
SPV 65 & 2.7 & 1.6 & 1.4 & 3.0 & Too dry \\
SPV 52 & 3.0 & 1.8 & 1.2 & 2.5 & Too dry, too gray \\
SPV 64 & 4.2 & 2.8 & 3.1 & 4.5 & All comments positive \\
SPV 55 & 4.8 & 3.4 & 3.7 & 4.8 & All comments positive \\
SPV 56 & 3.4 & 2.4 & 2.9 & 4.5 & All comments positive \\
\hline
\end{tabular}

${ }^{1}$ Family comments adjusted to a scale of 1 to 5 for comparability.

(scales 1 to 4 ), the acceptance by the family (scale of 1 to 3 ) and an opportunity to comment favorably or unfavorably. Table 4 presents the results of this study

In the fourth study (Haiti), whole sweet potatoes of 9 selections were boiled in large pots over outdoor fires and were served as wedges of a cross section to 3 groups of young Haitian horticulturists who were attending short courses on sweet potato. The groups ranged in size from 14 to 27, but not all tasted or evaluated every selection. The students were asked to evaluate the selections as very good, good, or less than good. Table 5 shows the results.

In the fifth trial (Hormigueros) 7 boiled selections were presented to 56 to 71 persons in a home for the elderly. They were asked 5 questions, each on a scale of 1 to 3 as follows: Is this sweet potato attractive (moist, of good flavor, sweet, a good one)? These questions correspond to the characteristics previously presented. The results are presented in table 6.

\section{RESULTS}

Table 2 shows the sensory evaluation of 9 selections of sweet potato by a trained taste panel. No statistically significant differences were observed in appearance among the samples. All were found acceptable in appearance. Flavor of all samples were acceptable, except for SPV 52 (poor). There was a significant difference at the 5\% level between this selection and all others. The highest scored were SPV 44 and SPV 55.

Selections SPV 44, 46, and 60 were judged sweetest. Selection SPV 52 was found low in sweetness. There were highly significant differences between SPV 52 and all other selections studied. Significant difference in sweetness was also found between selections SPV 44 and SPV 71.

All were well accepted for texture (mouthfeel) and were rated highly for overall acceptability, except SPV 52, ("Fair" in texture, "dislike moderately" in overall acceptability). The average score of all other samples 
TABLE 5.-Studies of acceptability of 9 sweet potato selections among Haitian agronomists at at three locations

\begin{tabular}{|c|c|c|c|c|c|}
\hline \multirow[b]{2}{*}{ Selection } & \multicolumn{3}{|c|}{ Locations } & \multirow[b]{2}{*}{ Total } & \multirow[b]{2}{*}{ Point Score ${ }^{1}$} \\
\hline & Les Cayes & Croix des Boquete & Gonaïves & & \\
\hline \multirow[t]{3}{*}{ SPV 66} & $10^{2}$ & 4 & 01 & 15 & \\
\hline & 12 & 7 & 11 & 30 & \\
\hline & 4 & 2 & 9 & 15 & 2.0 \\
\hline \multirow[t]{3}{*}{ SPV 63} & 6 & 8 & 14 & 28 & \\
\hline & 18 & 6 & 6 & 30 & \\
\hline & 2 & 0 & 0 & 2 & 2.4 \\
\hline \multirow{3}{*}{ SPV 60} & 6 & 0 & 11 & 17 & \\
\hline & 14 & 5 & 11 & 30 & \\
\hline & 6 & 5 & 0 & 11 & 2.1 \\
\hline \multirow[t]{3}{*}{ SPV 70} & 14 & 2 & 9 & 25 & \\
\hline & 13 & 5 & 13 & 31 & \\
\hline & 0 & 4 & 0 & 4 & 2.4 \\
\hline \multirow[t]{3}{*}{ SPV 65} & 5 & 2 & 14 & 21 & \\
\hline & 19 & 5 & 8 & 32 & \\
\hline & 3 & 4 & 0 & 7 & 2.2 \\
\hline \multirow[t]{3}{*}{ SPV 52} & 10 & 5 & 0 & 15 & \\
\hline & 8 & 5 & 18 & 31 & \\
\hline & 9 & 3 & 1 & 13 & 2.0 \\
\hline \multirow[t]{3}{*}{ SPV 64} & 4 & 0 & 0 & 4 & \\
\hline & 12 & 8 & 17 & 37 & \\
\hline & 9 & 2 & 4 & 15 & 1.8 \\
\hline \multirow[t]{3}{*}{ SPV 55} & 2 & 6 & 0 & 8 & \\
\hline & 20 & 5 & 3 & 28 & \\
\hline & 2 & 2 & 17 & 21 & 1.7 \\
\hline \multirow[t]{3}{*}{ SPV 56} & 13 & 3 & 3 & 19 & \\
\hline & 15 & 8 & 18 & 41 & \\
\hline & 1 & 1 & 0 & 2 & 2.3 \\
\hline
\end{tabular}

' Obtained by assigning 1 point to less good, 2 to good, and 3 to very good, divided by number of observations.

${ }^{2}$ Number of persons who rated the selection, very good, good, less good, in descending order.

TABLE 6.-Reactions of elderly people to 7 sweet potato selections

\begin{tabular}{|c|c|c|c|c|c|c|}
\hline \multirow[b]{2}{*}{ Selection } & \multirow[b]{2}{*}{$\begin{array}{l}\text { No. of } \\
\text { people }\end{array}$} & \multicolumn{5}{|c|}{ Mean ratings for } \\
\hline & & Appearance ${ }^{i}$ & Texture ${ }^{2}$ & Flavor $^{1}$ & Sweetness ${ }^{1}$ & $\begin{array}{c}\text { Overall } \\
\text { Acceptability }\end{array}$ \\
\hline SPV 66 & 64 & 4.8 & 3.0 & 4.2 & 3.0 & 4.4 \\
\hline SPV 63 & 62 & 5.0 & 3.8 & 4.6 & 3.0 & 4.6 \\
\hline SPV 60 & 65 & 4.5 & 3.0 & 4.4 & 3.1 & 4.5 \\
\hline SPV 52 & 9 & 3.2 & 1.0 & 2.2 & 1.0 & 1.7 \\
\hline SPV 64 & 71 & 4.8 & 3.0 & 4.5 & 3.1 & 4.3 \\
\hline SPV 55 & 56 & 4.4 & 3.3 & 4.6 & 3.4 & 4.7 \\
\hline SPV 56 & 62 & 4.5 & 3.0 & 4.5 & 3.1 & 4.8 \\
\hline
\end{tabular}

${ }^{1}$ Mean ratings for $1-5$ on the same scales as in table 2.

${ }^{2}$ High ratings indicate moister mouthfeel. 
in overall acceptability was between "like" (4 points) and "neither like nor dislike" ( 3 points). For both characteristics there were significant differences between SPV 52 and other selections.

Table 3 shows the results of the panel ratings of 8 selections. Selections were significantly different in all characteristics. The value for acceptability is a summary rating or judgement which ranged from 1.9 (minimum acceptability) to 3.7 (good). Selections SPV 70, 63, and 56 received the highest score for acceptance, and selection SPV 52 was lowest in acceptability. The judgement of appearance ranged from 1.9 (poor appearance) to 3.8 (good appearance). Selection SPV 52, lowest in acceptability, was also lowest in appearance. Highly acceptable selections were among the most attractive. Mouthfeel, judged from driest to wettest, varied from 1.6 (dry) to 4.0 (moist). The least acceptable selection was the driest in mouthfeel. The most acceptable selections were intermediate in mouthfeel, neither dry, nor very moist. Flavor ratings ranged from 2.3 (slightly better than poor) to 3.9 (good). The least acceptable selection had the lowest flavor rating whereas the most highly acceptable selections has good flavor. Sweetness ranged from 1.2 (not sweet) to 3.5 (between sweet and very sweet). Both the least and the most acceptable selections were non-sweet.

Significant correlations (Table 7) were found between appearance and mouthfeel $(r=0.71)$, and appearance and flavor $(r=0.72)$. Mouthfeel was highly correlated with flavor $(r=0.80)$. Mouthfeel was also significantly correlated with acceptability $(r=0.73)$. Sweetness was not significantly correlated with acceptability or with any other quality characteristic.

Ratings by families in the home were adjusted to fit the 1 to 5 scale used for evaluation by the public. These ratings, coming from a nonhomogenous population, were not analyzed statistically but are summarized in table 4 and a few comments are given. The selections found to be highly acceptable by the panel, SPV 70,56 , and 63 , were also highly rated by families. The selection SPV 52 was again poorest in acceptability. The average ratings for appearance, texture, and sweetness are comparable to the ratings given by the panel. Comments for the entire group were favorable, with SPV 52 receiving an excess of negative com-

TABLE 7.-Convelations among ratings of sweet potato and of overall acceptability

\begin{tabular}{lcccc}
\hline Characteristic & Mouthfeel & Flavor & Sweetness & $\begin{array}{c}\text { Overall } \\
\text { acceptability }\end{array}$ \\
\hline Appearance & $.71^{* 1}$ & $.72^{*}$ & .32 & .48 \\
Mouthfeel & & $.80^{* * 2}$ & .42 & $.73^{*}$ \\
Flavor & & .45 & $.82^{* *}$ \\
Sweetness & & & & .29 \\
\hline
\end{tabular}

${ }^{1}$ Significant correlation $(\mathrm{P}<05)$.

${ }^{2}$ Highly significant correlation $(P<01)$. 
ments. Families responded negatively to very dry, mealy selections. Sweetness appeared to be expected by some families but not by others. Selection SPV 70 was perceived to be like the potato, Solanum tuberosum and highly favored.

Among the Haitian agronomists the selections most accepted were SPV 70 and 56. The selections least accepted were SPV 55 and 64, the sweetest (table 5). There appeared to be some differences in acceptance in the three regions.

People in a home for the elderly liked all of the sweet potatoes selections tested (table 6). Selection SPV 52, however, was rated lower for all of the characteristics tested and for overall acceptability. All selections except SPV 52 were rated average in sweetness. While the selections SPV 63, 66, 60, and 64 were rated high for all other characteristics except texture (rated intermediately), SPV 55 and SPV 56 received slightly higher ratings.

\section{DISCUSSION}

In these studies five distinct groups of people have had the opportunity to evaluate in some type of sensory tests a number of new selections of sweet potato. These selections differed in many characteristics, but all had been carefully selected for one or several important traits. They were not compared to standard varieties because there is no consensus of standard varieties in the Caribbean area nor of varieties that are well known in the islands.

It is evident that the different groups evaluated the sweet potatoes at different levels of sophistication. In fact, the scales used reflected both the expected experience of the group tested, as well as time available for testing. The elderly, for example, did not notice differences as well as others and tended to rate high. The Haitian agronomists were sophisticated about the sweet potato and showed strong likes and dislikes. The taste panel appeared to have reached less uniform conclusions than the untrained panel, where more significant differences were seen. Yet the principal conclusions were much the same for all groups. All of the sweet potato selections were found to be acceptable with the exception of SPV 52 , which is distinguished by its lack of sweetness, very dry texture, and grayish flesh on cooking. This selection can be useful in processing (frozen pulp, flour, starch).

Sweetness does not appear to be an important characteristic related to the acceptability of the new selections. Nevertheless, some persons downgraded certain selections because sweetness was expected and not found. Flavor, texture, and appearance appear to be more important. The high correlations observed among quality characteristics were not expected. Nevertheless, it appears that the grayness due to polyphenolic oxidation, which detracts from appearance, also gives a disagreeable 
flavor. Texture or mouthfeel should be neither too dry nor too moist for optimum satisfaction.

Selection SPV 52, which was the first non-sweet selection developed by the author and was considered a prototype (5), was not well accepted by any group, and has now been surpassed by better non-sweet selections. The non-sweet selection SPV 70 and low sweet selection SPV 71 are similar in appearance and taste to the potato and appear to have potential as Irish potato substitutes.

Perhaps the most useful aspect of this research is the demonstration that it is possible to breed acceptable cultivars for the tropics, including non-sweet types as Irish potato substitutes.

\section{RESUMEN}

Evaluación sensorial de nuevas selecciones de batata

Doce nuevas selecciones de batata, que variaba en muchas características visibles, se evaluaron después de cocerse por 5 grupos de personas: un grupo entrenado, uno no entrenado, familias en sus hogares, agrónomos haitianos $y$ residentes en un hogar de ancianos. Se evaluaron para apariencia, textura, sabor, dulzura y aceptabilidad general. Solamente una selección fue rechazada por todos los grupos, SPV 52, un tipo no dulce y muy seco. Las selecciones más aceptadas fueron SPV 44, 55, 56, 70 y 71 . La selección SPV 70 no es dulce, pero recibió evaluaciones altas de los haitianos, las familias y el grupo no entrenado. Dos tipos mameya ${ }^{4}$ fueron bien aceptados: SPV 43 y 46 . La aceptabilidad general estuvo correlacionada con la fextura y el sabor, pero no con la apariencia y la dulzura.

\section{LITERATURE CITED}

1. Gull, D. D. and Conover, R. A., 1977. Quality characteristics and nutritional composition of boniatos (Ipomoea batatas). I. Cultivar quality. Proc. Fla. State Hort. Soc. 90:199201.

2. Kramer, A., 1963. Revised tables for determining significance of differences. Food Technol. 17 (12):1596.

3. Larmond, E., 1977. Laboratory Methods for Sensory Evaluation of Food. Research Branch. Can. Dep. Agric. Publ. 1637.

4. Martin, F. W., 1986. Sugars and starches in staple type sweet potatoes as affected by cooking and storage. J. Agric. Univ. P. R. 70:121-26.

5. — and Deshpande, S., 1985. Sugars and starches in a non-sweet sweet potato compared to conventional cultivars. J. Agric. Univ. P. R. 68:423-32.

6. - 1984. Identification of quality characteristics of sweet potato used as a staple food in the Caribbean. Caribbean Food Crops Society 19:249-54.

7. S-101 Technical Committee, 1980. Sweet Potato Quality. Southern Cooperative Series Bull. 249. Russell Research Center. Athens, Georgia. 